\title{
NAMING ME, NAMING YOU. PERSONAL NAMES, ONLINE SIGNATURES AND CULTURAL MEANING
}

\author{
CHARLOTTE HAGSTRÖM \\ Lund University
}

\section{A B S T RAC T}

Every day we talk and speak and chat to people. We write and listen to each other, refer to each other, describe to each other what we and others have done and said. Doing this, we sometimes use our given names, sometimes we go by our nicknames, which often indicate or clarify who we are or are made up by ourselves to draw other people's attention. Nicknames can be official or informal, known by many or only by a few, real monikers or made up pseudonyms or signatures. Where ever there are people there are names, since names are and have always been part of human life. Sociologist Richard D. Alford states that ethnographic research has not found a single society whose members do not have names (Alford 1988, 1). Names are cultural universals, something all humans have in common, no matter where or when they live.

This article focuses on personal names and naming from a cultural ethnographic perspective. It begins with reflections on the link between name and self, continues with a discussion of how names are used to culturally structure our surroundings and interpret the world, and concludes with an analysis of names used in virtual settings. The virtual field has hitherto not received much interest among name researchers. In online games, chat rooms and web communities, names are not only useful and applicable, as they are in the so called real world; they are even more essential and important as it is mainly through their names participants recognise and identify each other.

\section{[1] MY NAME AND YOURS}

While working on a project on personal names Hagström (2006), one question of interest was how the informants viewed their own names and what the name meant to them. A person's own name is important because it distinguishes her as a unique person and identifies her as herself. One informant explained his thoughts about names and personal identity in the following way: "The name really doesn't have anything to do with identity but as it is a word that means oneself it gets an enormous importance".

This is something good coaches and pedagogues understand and make use of. Several sports clubs and organisations state in their instructions for coaches 
and leaders the importance of addressing players and team members by names. A Swedish basketball club writes under the heading "Leadership Policy" that coaches should "Address the players with their first names at least once every practice. It is important that they feel included." (Ängelholm basketball's website, (Ängelholm 2009), my translation), while a jujutsu club encourages their instructors to play name games: "Name games are games where you learn each other's names, and are particularly important at the beginning of the semester and in new groups. When everyone has a name to their face $s /$ he also has an evident spot in the group". (Älvsjö jujutsu club website, (Älvsjö 2009), my translation).

The same approach is used in class rooms and schools, but not always as a means to acknowledge a child or youth in a positive way. In her dissertation on teachers' work and knowledge creation, Ann-Sofie Wedin points out how several of the teachers interviewed say they benefit from knowing the names not only of their own but also other teachers' students: "It's something that makes students feel comfortable and important when they are in conflict with each other in the corridor. If you can address them by their name you can do so with a lot more authority than when you say "you there", which is something they had had to do every now and then and experienced as a much less successful approach" (Wedin 2007, 135), (my translation). Being addressed by your name means that you are seen and recognised; you are not just another person in the crowd. The coach (or teacher or instructor) sees what you do and it is your performance that is approved. This makes a difference when it comes to building up self-esteem and confidence.

Naturally, the opposite is equally true. To have your own name questioned is to be questioned as a person. Informants with immigrant background have often experienced this. One woman, who as a child bore her father's African family name, said teachers almost always mispronounced it. It was not a big issue, but she felt the comments that often followed were said in a derogatory manner and made her upset: "or however it is to be pronounced". They felt abusive and insulting. Another informant used to sing in the same choir as a girl with a French name. The choir master could never learn to pronounce it correctly and used different versions at every rehearsal. The girl found it very disturbing, feeling she caused problems and was embarrassed by this. The informant says she has talked about this with her friend now as they are adults and “...how stupid it was that it was she who would feel ashamed! It was he who should have felt ashamed because he couldn't pronounce her name! And it wasn't she who was a problem or caused trouble, he was the trouble. But she actually had to feel ashamed because she had this strange name".

Other persons' names are also important. They function as a means for us to form an opinion about who the person, whose name we see or hear, "is". Erving Goffman describes how people, when they stand in front of a person whom 
they do not know, "can glean clues from his conduct and appearance which allow them to apply their previous experiences with individuals roughly similar to the one before them" and "apply untested stereotypes to him" (Goffman 1969, 13). This is applicable also to their reactions to personal names. A Swede who learns that a person's name is Mohammed will sort him into categories such as "man", "Muslim" and "immigrant". A Tuva will be sorted into the categories "female", "young" and "Swedish".

Our images of who Mohammed is and who Tuva is, based on their names, may be true. But they can also turn out to be erroneous. To find that the new neighbour called Berit, which is a very unusual name for Swedish girls but common among women in their 60 's, is only 5 years old may be amusing. Or, as a teacher, to find that the Japanese student in your class named Akira is not a woman as you reckoned, based on the fact that almost every name ending with an "a" in Swedish is female, probably does not matter. But this does not mean that the categorisations we make, consciously or unconsciously, are unproblematic.

\section{[2] CATEgORISATION AND SYSTEMATISATION}

A statement frequently made by informants is: it does not matter what you are called, it is what you do and say that counts. Most people would probably agree that this is how it should be. Whether you are called Jutta or Joline, Pierre or Pentti you should not be judged, treated or measured differently. But that is not how it is. Based on our preconceived notions about other people's names we draw conclusions about their gender, age, ethnicity, nationality, social positions, and maybe even religious beliefs. The "name factor" influences our behaviour and attitude towards them as well as our expectations of their attitude towards us. From this follows that it does matter what you are called.

To categorise animals, people, plants, objects and everything else that we encounter helps us comprehend and understand the world. Social anthropologist Claude Lévi-Strauss states that names are essential in this process (LéviStrauss 1996 [1962]). With the help of names we create order and we structure our conception of the world. Through naming we make the world understandable. We classify and arrange our environment by separating it into named categories and filling them with named components. For example, a category of activities called "sports" is separated into sub-categories like "team sports" and "individual sports" and although not all "team sports" and all "individual sports" are the same, these categories can still be distinguished from one another and a certain order achieved. Within the team-sports category, sub-divisions exist, for example, football, handball and so on. In our language, there are complex systems of main and subcategories; all of them are named and thus distinguishable from each other. 
The process of systematisation and categorisation does not only help us structure our lives and make the world comprehensible; it also regulates our thinking and restricts our perspectives. It thus renders other possible systems of categorisation invisible or even unimaginable: "Although categorization may normally be a useful tool for processing the social world, it can sometimes result in unfair or incorrect inferences" write psychologists Jennifer T. Kubota and Tiffany A. Ito (Kubota \& Ito 2009, 335). For example, is it possible to un-think gender, to envision an everyday life where the categorisation of people into men/women does not exists? Labelling children as boys or girls rather than children is often done in a routine-like way, and their behaviour and manners are understood and interpreted in terms of gender; a boy is expected to behave - or not behave in a certain way because he is a boy. As Kubota and Ito points out there is a link between categorisation, stereotyping and prejudice (ibid). When gender categorisation is applied by a teacher or other pedagogue in a school or pre-school, thus resulting in the reinforcement of stereotypes, he or she acts in direct contravention to what is stated in the Lpo 94, the curricula and the government's ordinance for the Compulsory School System, the Pre-School Class and the Leisure-time Centre: "Democracy forms the basis of the national school system [...] The inviolability of human life, individual freedom and integrity, the equal value of all people, equality between women and men and solidarity with the weak and vulnerable are all values that the school should represent and impart" (Lpo94 2006, 3).

Since 2006, all schools and pre-schools must set up an equality plan with a policy on how to handle issues concerning gender, diversity, discrimination etc. One way to counteract the negative effects of gender stereotyping is making oneself aware of how to address the children: "When addressing someone the staff uses the children's names and avoid gendering animals or things" one pre-school state in its annual quality report (Kvalitetsredovisning läsåret 2007/2008, Svartöstaden förskola, (Kvalitetsredovisning 2008), my translation). Another school writes under the heading "Equality" in their work plan that they "address the child by its name, not by, for example, 'the boy or the girl"' (Arbetsplan för Gläntans förskola 2008, (Arbetsplan 2008), my translation). The fact that these pre-schools have found it important to formulate their naming policy in writing demonstrates how we seldom reflect upon the fact that we constantly categorise our environment; we take the way we address people, things and animals for granted.

We also favour certain ways of classifying and systematising the world before others; our own schemes and structures do not only seem normal but also natural. If the categories are questioned, it is often difficult to explain exactly what makes them so natural: they just are. A Norwegian or German probably does not reflect very often on the fact that people in Norway and Germany have surnames. In the same way, a Chinese does not think about the fact that $\mathrm{s} /$ he places his or her family name first. To have a surname, or to place the family name first, comes 
naturally. Not until we come across other naming practises do we recognise our own systems of categorisation as just that, a system firmly in place.

Different people have different tastes in names, often based on personal experiences: we tend to like the names of people we like, while we dislike names associated with people we do not like. But the personal aspect is only one factor; our conceptions of names are primarily based on cultural knowledge. There are vast differences as to what is considered a possible and suitable name. While Swedish and Dutch names are, more or less, specific words used only for identifying a person, Chinese names are also common words. Jian Guo is a name, but it also means "establish" and "country" ${ }^{1}$ The context determines if the expression is referring to a person, a place or a word. This means that it is sometimes possible to deduce the age of a person through his or her name. The meaning of Jian Guo reveals it is a name given around the time of the establishment of the People's Republic of China (see also Lu \& Millward 1989).

As we constantly see and hear names of people around us, we learn to connect them with gender, age, class, and so on. But this knowledge, our "sense" of a particular name, may not be at all relevant in another cultural context. For example, Magnus was one of the most popular names among boys born in Denmark in 2008 (Danmarks Statistik's website, (DST 2009)). In Sweden, however, the name was not given to a single newborn boy that year (Statistiska Centralbyrån's website, (SCB 2009)). From a Swedish perspective Magnus is a name that belongs to a different generation; the father of the newborn boy is more likely to bear that name, or even his grandfather. ${ }^{2}$ Thus, despite the fact that these two countries have a lot of things in common, among them a relatively similar naming custom, the cultural knowledge and experience amassed in one of them is not necessarily translatable to the other.

Names help us navigate in social and cultural spheres. Names are not neutral. We use names to identify ourselves and others, to make the world understandable and to create order.

\section{[3] VIRTUAL NAMES}

But how, then, do names and categorisation work in a setting where the name is not only one of several factors distinguishing a person from other, but sometimes the only factor? This is often the case in various virtual milieus and on-line communities. Questions such as what kind of names are used, why, and how they are perceived, seem all the more relevant as more and more people spend more and more time in virtual worlds, such as Second Life, and different massively multiuser online role-playing games, MMORPG's, such as World of Warcraft. People also

[1] Thanks to Hanzhi Jiang for providing this example.

[2] Since 1998 Magnus has not been on the top 100 list of names of newborn boys in Sweden. That year it ranked number 89. At the same year it ranked number 16 Denmark and in 2005 it rose to number 2. 
write and read blogs, they join virtual communities, send e-mails, do business online, share photographs and films, and so on. Whatever they do and for whatever reason, they do it under a specific name. ${ }^{3}$ These names may be their own real names, but are often particular names coined for a particular setting. On-line and in virtual worlds, names are not only as necessary and essential as they are off-line and in the so-called real world. They are even more important and indispensable. I will here present some brief examples from two different projects on how names are being used and perceived on-line. The first is a completed project, which resulted in the article "Playing with Names. Gaming and Naming in World of Warcraft" (Hagström 2008). The other is an on-going project called Behind the Names. Experiences and Consequences of Names used in Virtual Settings.

Creating a character, an avatar, in World of Warcraft, the world's biggest MMORPG with over 11,5 million users, includes settling on a name for it (Blizzard 2008). The game producer, Blizzard Entertainment, has issued a name policy, and as long as the individual player does not violate it she is free to choose whatever name she wants. The possibilities to create a visibly unique avatar are not endless and thus a player may now and then find her own character facing another character, run by another player, looking very much the same. The name, on the other hand, has to be unique as there cannot be two avatars with the same name on the same server. ${ }^{4}$ This means it is the name, not the appearance, which distinguishes characters from each other. It is through their names players identify each other (Hagström 2008).

Finding people willing to share the narratives behind the names of their avatars turned out to be easy. Apparently there were lots of players just waiting to get a chance to tell their stories! A call for informants was placed on my university webpage, inviting who ever wanted to send me the history behind the name, and I soon received answers. The first was followed by another, then another and another. They came from all over the world and from people of all ages. Even though the article those stories were solicited for is long since published, and I have a new official webpage which says nothing about the project, I still receive stories. The old page is still out there somewhere and now and then it is found by someone who has a story to share. For example, in August 2009, a 22-year-old woman from the Netherlands sent me an e-mail explaining how she used to include variations of Tigris in the names of her characters. The name "I simply found one day years ago in geography class when we talked about the rivers Eufraat [the Euphrates] and Tigris". In January the year before, another

[3] In the following discussion I make no difference between nicknames, names of avatars, pseudonyms or signatures but refer to all of them as "names". All quotes are verbatim.

[4] It should be noted there are other areas where names also need to be exclusively individual. One is the world of harness racing. The naming of a trotting horse has to follow certain rules and every horse has to have a unique name. (Berglund 2006, 159), personal communication with Rolf Hedquist (2010-07-01) 
player, introducing herself as a 37-year-old mother, wrote about how she at first had tried to use a name generator but soon realised "that NONE of the names fit me, my toon, what I felt I wanted to be represented by in the game" and decided to come up with one by herself. ${ }^{5}$

Other stories reached me in the form of responses to the same call for informants posted on the blog jill/txt (jill/txt 2006). This is run by one of the editors of the book where the first article eventually was published. As of April 2010, there were 251 responses to this thread, the last one posted the same month. The posts consist mainly of replies that contain explanations of various names and the history behind them, and replies that plainly list names, occasionally leaving short comments. There are also replies that use the thread not for telling about a name but for finding one, like Bloodreaperr who in July 2007 wrote: "Hey im havin trouble with gettin a good name for an orc warrior i wanna make, any suggestions?" In November 2008, Ivan presents a list of 16 names with explanations. He writes that he sometimes "sit for long periods of time just to come up with a new name. It's a time consuming process sometimes" but "[I hope] ive enfluenced your toon naming in a positive way".

From reading the names and the explanations in e-mails and blog posts, it can be concluded that people are tremendously creative and imaginative. Inspiration comes from almost all sources imaginable: board games, Greek dramas, J. R. R. Tolkien's Lord of the Rings, Nobel laureates, gods and goddesses from ancient Roman, Celtic, Greek, Norse and Egyptian religions, medicine, sports, video games, the Bible, Manga literature, films, childhood memories, comics, other languages than English, stars, places bearing a personal meaning, family pets, and so on (Hagström 2008). Whichever name that finally is chosen for the avatar, it is through this name the player is recognised by other players. Just like in the world outside of the game, one and the same name can be perceived differently by different players. Several informants explain how some types of names are perceived in a negative way and even can affect game play. Nonsense names, such as Hgrwhsjx, or names taken from real life objects, such as Lampshade, are considered stupid and ruining the "feeling" of the game. The same goes for names that are too obviously influenced by somebody else's imagination, like names reminding very much of the ones invented by Tolkien. Players using these kinds of names are probably, they say, not people who view the game in the same way as they do. As a consequence, they sometimes avoid to group, chat or interact with these players.

Names function the same way in virtual settings like forums and communities. Unlike in the off-line world, where names are one of several factors through which we recognise and differentiate people, here it is often the only distinguish-

[5] E-mails received 2009-08-08 and 2008-01-19. 
ing factor. It is of course possible to learn to recognise a person one chats with frequently through her personal style of writing, like vocabulary, repeated grammatical errors, expressions and so on. But, in general, a person, who logs into a web community and finds 58 new posts written by other members, has no other means to know who has written which post than going by the names.

Some names can look very similar: there can be one 4JackM and one M4Jack writing in the same forum. This means spelling is crucial. In "real" life, it may not make a big difference if we forget an $\mathrm{H}$ in Elizabeth. In virtual life, it can be of extreme importance: one letter forgotten in the recipient's name and the e-mail bounces back - or goes to the wrong person!

The names used in on-line computer games, virtual worlds, and web communities are often very different to the ones used in the "real" world. To meet someone called Wlmth52 or Hulahoop online is not uncommon. But does it not matter, then, what name you choose for yourself on-line? Is Honeybaby or MumboJumbo as functional and sensible as Sam Williams or Lisa? How does it influence your jobseeking process, when you submit your application from an e-mail address like Party_Pete@hotmail.com? How do we form an opinion of somebody, when all we have to base our interpretations on is their name?

\section{[4] JIMMY91 AND BARCA_10}

Questions like these were in focus when I, one afternoon, met with a group of four children, two girls and two boys aged 10-11, for an interview about names on the internet. The children, who had met me before, were all in the same class and thus knew each other when they sat down at my kitchen table, a little nervous but mostly excited about being interviewed. We had cookies and juice and soon they forgot the recording device and plunged into a discussion on names, games and the internet. One of the girls and one of the boys played World of Warcraft, the two girls played Go Supermodel and all of them chatted regularly with friends on MSM. It also turned out that currently all the children in the class where involved in the browser game Travian where they ran a village together, fought wars and formed alliances with neighbours. All players had to choose a nickname and they explained to me which classmate had which name. One of the girls present explained her choice of name, Tennisbollen [The Tennis ball], with her being interested in ball sports and thus often choosing that type of name: in another online environment she used the name Basketbollen [The Basketball].

Before meeting the children, I had prepared a paper with 9 groups, each consisting of 10 names. These I had collected from various discussion forums and communities on the internet. I presented them to the children together with another paper where I had listed the names of the communities and asked them to place each group of names under the correct heading. While my main objective was to learn how the children reasoned around and discussed the names, and their 
motivation for placing them in one group or another, they found the exercise an exciting challenge. When I afterwards told them they had found the right heading for each group they cheered and shouted "full score!" obviously very pleased with themselves!

The names used by the members posting in the various forums consisted of real-world names in various combinations, such as Albin, YlvaA and Jimmy91, and made up names of all kinds, such as zerounozero, Rosenmannen [The Rose Man] and Regndroppe [Raindrop]. They were collected from threads concerning a specific topic within each web community or discussions group, which in turn were focused on a broader subject: film, poker, tango, family, EPA-tractors ${ }^{6}$, gardening, video games, football and Harry Potter.

In a study of how Chinese internet users, who frequent the bulletin board Qiangguo Luntan (QGLT), construct themselves as politically active, Robert G. Tian and Yan Wu discuss the participants' choices of names. Here, they say, pennames play an important part as they are used for expressing and underlining opinions. Examples are "Zhonghua shi wo qin'ai de jia (China is my beloved motherland)", "Ti xiagang shiye zhigong shuoju gongdaohua (speaking out for the unemployed workers)" and "Minzhu qingchu fubai (democracy eradicates corruption)" (Tian $\& \mathrm{Wu} 2007,244)$. A tentative hypothesis for the project Behind the Names is that participants and members of online discussion groups often choose a name related to the overall theme of the group. By doing so they show other participants that they are familiar with the topic, aware of potentially shared knowledge (which can be very specific and exact) and eager to contribute to strengthening the group as a cultural community.

The children's' discussions about where to place which name supported my idea that this feature is apparent even for an outsider who does not necessarily possess all the previously shared knowledge. That Volvo740turbo and chevy64 were names used by people posting in the community focusing on cars was not very difficult to guess, neither was deducing that Barca_10 belonged to the football community and Spelpojken [The Gameboy] to the one about games. Other names where more difficult to place; in the tango community in fact none of the names were related to dance.

The discussion among the children and the arguments they presented to each other showed that a single name was often felt to fit under more than one heading. It was in relation to other names in the same group that it became characteristic or typical. Thus Smaragd [Emerald] could be placed in any of the categories, but together with names such as Hedwig and mona.riddle it had to be about Harry Potter as all three together did not fit any of the other groups. In some communities the topic-specific names were more common than in others. In the car commu-

[6] An EPA-tractor is type of customized car - often a rebuilt Volvo.

See http://sv.wikipedia.org/wiki/EPA-traktor 
nity more than half of the names were associated with cars while the children found only one such name in the garden community. Not surprisingly, the discussion also showed that the more familiar you are with a topic, the easier it is to recognise and connect a sometimes obscure name with that topic. Thus the children, who had visited enough websites and forums concerning films, games and the Harry Potter universe to be familiar with the prevalent naming customs, easily identified several names as belonging to such communities even though they sometimes were rather obscure and far-fetched. Similarly, there were names that they did not connect to a certain topic but which someone more familiar with it would have identified at once.

The use of names in virtual settings, such as online communities and games, has previously not been the focus of much scholarly interest. It is rather surprising as the naming, of yourself or of your avatar, usually is a necessary step to go through before participating in any such activities. Without a name you cannot play, chat or post. Similarly, other players' and participants' names are essential as it is through their names we recognise and identify them. Though there are some studies addressing these issues, such as Haya Bechar-Israeli's study on nicknames and identity on IRC (internet relay chat) (Bechar-Israeli 1995), and Heisler \& Crabill's study of how different e-mail names are perceived (Heisler \& Crabill 2006), there is still a lack of knowledge. As sociologist Katja M. Guenther writes in an article on whether to use real names or pseudonyms in fieldwork and research, and the effects and result these choices have, the issue of naming is essential: "The act of naming is an act of power. Parents naming children, conquerors naming new lands, and organisations naming themselves all involve the assertion of authority and control" (Guenther 2009, 412). See also Alderman (2009). Studying names found in virtual environments, and exploring the motives behind the users' choices, the methods they apply for deciding upon them and how they interpret and conceive others' names and their choices, not only gives us information on naming customs and habits. It also helps us understand how people - as users, players and participants - see themselves and their place and position in relation to others.

\section{REFERENCES}

Alderman, D.H. 2009. Virtual place Naming, Interent Domains, and the Politics of Misdirection: The Case of www.martinlutherking.org. In Berg, Lawrence D. \& Vuolteenaho, Jani (eds): Critical Toponymies. The Contested Politics of Place Naming, Farnham: Ashgate.

Alford, R.D. 1988. Naming and Identity. A Cross-Cultural Study of Personal Naming Practices. New Haven: HRAF Press. 
Älvsjö. 2009. Ävsjö jujutsuklubb.

http://www.alvsjojjk.org/Jutsu_do_hemsida/uppvarm.htm. Retrieved 200910-07.

Ängelholm. 2009. Ängelholm basketball's website.

http://www.alibasket.se/doc/Aliten.pdf. Retrieved 2009-10-07.

Arbetsplan. 2008. Arbetsplan för Gläntans förskola.

http://www2.karlskrona.se/spandelstorp-ro/Glantan/dokument/

Arbetsplan.pdf.

Bechar-Israeli, H. 1995. From <Bonehead > to <cLoNehEAd>. Nicknames, Play, and Identity on Internet Relay Chat. Journal of Computer-Mediated Communication Vol. 1 , no. 2.

Berglund, S. 2006. Vägen till vinnarcirkeln. Travhästen och dess människor mellan sport och spel. Stockholm: Gidlunds.

Blizzard. 2008. Blizzard entertainment: World of Warcraft subscriber reaches 11,5 million worldwide.

http://eu.blizzard.com/en-gb/company/press/pressreleases.html?081223.

Retrieved 2009-10-14.

DST. 2009. Danmarks statistik. Mest populære navne for danskere født i et bestemt år.

http://www.dst.dk/Statistik/Navne/NamesPop.aspx?period. Retrieved 200910-07.

Goffman, E. 1969. The Presentation of Self in Everyday Life. London: Penguin.

Guenther, K. 2009. The politics of names: Rethinking the methodological and ethical significance of naming people, organizations, and places. Qualitative Research Vol. 9, no. 4.

Hagström, C. 2006. Man är vad man heter. Namn och identitet. Stockholm: Carlssons.

Hagström, C. 2008. Playing with names. Gaming and Naming in World of Warcraft. In Corneliussen, Hilde and Walker Rettberg, Jill (eds): Digital Culture, Play, and Identity. A World of Warcraft Reader, London/Mass: MIT Press. Translated by Jessica Enevold.

Heisler, J.M. \& S.L. Crabill. 2006. Who are 'Stinkybug' and 'Packerfan4'? Email Pseudonyms and Participants' Perceptions of Demography, Productivity, and Personality. Journal of Computer-Mediated Communication Vol. 12, no. 1. 
jill/txt. 2006. Answers to the post "Names in World of Warcraft" posted 2006-0419. http://jilltxt.net/.

Kubota, J.T. \& T.A. Ito. 2009. You Were Always on My Mind. How Event-Related Potentials Inform Impression Formation Research. In Nelson, Todd D. (ed.): Handbook of Prejudice, Stereotyping, and Discrimination, New York: Psychology Press.

Kvalitetsredovisning. 2008. Kvalitetsredovisning läsåret 2007/2008. Svartöstadens förskola.

http://www.lulea.se/download/18.cbcf80b11c19cd633e800023861/ kvalitetsredovisning.pdf.

Lévi-Strauss, C. 1996 [1962]. The Savage Mind. Oxford: Oxford University Press.

Lpo94. 2006. Curriculum for the compulsory school system, the pre-school class and the leisure-time centre.

http://www.skolverket.se/publikationer?id=1070.

Lu, Z. \& C. Millward. 1989. Chinese Given Names since the Cultural Revolution. Names 37.

SCB. 2009. Statistiska centralbyrån. Namnstatistik. Tabeller och diagram. http://www.scb.se. Retrieved 2009-10-07.

Tian, R.G. \& Y. Wu. 2007. Crafting self identity in a virtual community: Chinese internet users and their political sense form. Multicultural Education \& Technology Journal Vol. 1, no. 4.

Wedin, A.-S. 2007. Lärares arbete och kunskapsbildning. Utmaningar och inviter $i$ den vardagliga praktiken. Linköping: Institutionen för beteendevetenskap och lärande, Linköpings universitet.

Non published material

Interviews performed and e-mails received by the author. 
AUTHOR CONTACT INFORMATION

\section{Charlotte Hagström}

Department of Arts and Cultural Sciences

Biskopsgatan 7

S-223 62 Lund

Sweden

charlotte.hagstrom@kultur.lu.se 